\title{
PERBANDINGAN TINGKAT PENGEMBALIAN (RETURN), RISIKO DAN KOEFISIEN VARIASI PADA SAHAM SYARIAH DAN SAHAM NON SYARIAH DI BURSA EFEK INDONESIA (BEI) PERIODE 2011-2013']
}

\author{
Ajeng Gama Rosyida \\ Mahasiswa Program Studi Ekonomi Islam-Fakultas Ekonomi dan Bisnis-Universitas Airlangga \\ Email: ajenggama94@gmail.com \\ Imron Mawardi \\ Departemen Ekonomi Syariah-Fakultas Ekonomi dan Bisnis-Universitas Airlangga \\ Email: ronmawardi@gmail.com
}

\begin{abstract}
:
The purpose of this study was to determine the differences of rate of return, risk and coefficient of variation on Islamic stock and non-Islamic stock in Indonesia Stock Exchange (IDX) 2011-2013. This study was using quantitative approach with Mann-Whitney U test. The population in this study was Islamic stock and non-Islamic stock which listed on Indonesia Stock Exchange (IDX) within the time period (2011-2013). Determination of the number of samples using probability sampling, where the sampling randomly taken from members of the population without considering the level, and 10 Islamic stock and 10 non-Islamic stock where being selected. Data that being used was secondary data. The data was collected from official website of the Indonesia Stock Exchange (IDX). The results of this study showed that there was no significant differences of rate of return, risk and coefficient of variation on Islamic stock and non-Islamic stock.
\end{abstract}

Keywords : Rate of Return, Risk, Coefficient of Variation, Islamic Stocks, non-Islamic Stock

\section{PENDAHULUAN}

Investasi merupakan penempatan sejumlah kekayaan untuk mendapatkan keuntungan di masa yang akan datang (Huda dan Nasution, 2008:7). Investasi dalam bentuk surat berharga (sekuritas) biasanya dapat dilakukan melalui pasar modal (Astuti dan Sugiharto, 2005:251). Di Indonesia yang berperan sebagai pasar modal adalah Bursa Efek Indonesia (BEI).

Berdasarkan Fatwa No. 80/DSNMUI/III/2011 tentang penerapan prinsip syariah dalam mekanisme perdagangan efek bersifat ekuitas di pasar regular bursa efek, BEl menerbitkan Indeks Saham Syariah Indonesia (ISSI) yang dimaksudkan untuk menjadi acuan bagi investor untuk berinvestasi di saham. Adanya ISSI ini dapat dijadikan sebagai gambaran kinerja seluruh saham syariah yang tercatat di BEI.

Adapun jenis kegiatan usaha yang bertentangan dengan syariah adalah usaha perjudian dan permainan yang tergolong judi atau perdagangan terlarang; usaha keuangan konvensional (riba), termasuk perbankan dan asuransi konvensional; usaha yang memproduksi, mendistribusi, serta memperdagangkan makanan dan minuman yang tergolong haram; dan usaha yang memproduksi, mendistribusi, serta menyediakan barangbarang ataupun jasa yang merusak moral dan bersifat mudharat.

Adanya proses screening tersebut dapat menjadi pedoman bagi penduduk Indonesia yang mayoritas beragama 1] Jurnal ini merupakan bagian dari skripsi dari Ajeng Gama Rosyida, NIM: 041114015, yang diuji pada tanggal 13 februari 2015 
Islam. Sejak saat itulah, mulai timbul alternatif masyarakat selaku investor untuk berinvestasi pada saham yang diyakini memiliki nilai kehalalan dan juga dapat menghasilkan tingkat pengembalian (return) yang tinggi dengan risiko yang rendah, serta koefisien variasi yang rendah.

$$
\text { Penelitian Fahmi }
$$

menyatakan bahwa salah satu variabel yang menjadi bahan pertimbangan investor adalah risk dan return saham. Hal ini sesuai dengan kaidah fiqih yang telah dijelaskan oleh Djazuli (2011:133) bahwa risiko selalu mengikuti tingkat pengembalian (return):

$$
\text { الخَرَاجُ بِالضَّمَانُ }
$$

\section{Alkhorōju bīd\}d\}omānu}

"Manfaat suatu benda merupakan faktor pengganti kerugian."

$$
\text { العَرْمُ بِالَغَنْمِ }
$$

Algormu bilgonmi

"Risiko itu menyertai manfaat."

Arti keduanya adalah apabila ingin mendapatkan pengembalian, maka harus bersedia menanggung risiko.

Pada saat tingkat pengembalian (return) dari beberapa saham ialah sama, maka saham dengan risiko yang rendah akan dipilih menjadi saham yang lebih baik. Begitu pula sebaliknya, ketika yang sama ialah tingkat risiko dari beberapa saham tersebut, maka saham dengan tingkat pengembalian (return) yang lebih tinggi yang akan dipilih menjadi saham yang lebih baik. Namun, apabila return dan risiko dari saham tersebut memiliki tingkat yang sama, maka perhitungan yang diperlukan untuk membandingkan keduanya adalah koefisien variasi. Oleh karena itu, dalam penelitian ini, koefisien variasi mempunyai peran penting untuk membandingkan risiko per unit sahamnya. Dengan demikian, investor dapat melihat saham mana yang dapat memberikan tingkat pengembalian yang paling tinggi. Berdasarkan latar belakang di atas, penelitian ini bermasud untuk melihat apakah terdapat perbedaan antara risiko yang diukur dengan standar deviasi, tingkat pengembalian (return) dan juga koefisien variasi antara saham syariah dan saham non syariah di Bursa Efek Indonesia (BEI).

\section{Perumusan Masalah}

1. Apakah ada perbedaan antara tingkat pengembalian (return) pada saham syariah dan saham non syariah di Bursa Efek Indonesia (BEI) periode 2011-2013?

2. Apakah ada perbedaan antara risiko pada saham syariah dan saham non syariah di Bursa Efek Indonesia (BEI) periode 2011-2013?

3. Apakah ada perbedaan antara koefisien variasi pada saham syariah dan saham non syariah di Bursa Efek Indonesia (BEI) periode 2011-2013?

\section{Tujuan Penelitian}

1. Untuk mengetahui perbedaan antara tingkat pengembalian (return) pada saham syariah dan saham non syariah di Bursa Efek Indonesia (BEI) periode 2011-2013. 
2. Untuk mengetahui perbedaan antara risiko pada saham syariah dan saham non syariah di Bursa Efek Indonesia (BEI) periode 2011-2013.

3. Untuk mengetahui perbedaan antara koefisien variasi pada saham syariah dan saham non syariah di Bursa Efek Indonesia (BEI) periode 2011-2013.

\section{LANDASAN PUSTAKA}

Investasi merupakan kegiatan di bidang financial yang dilakukan untuk memperoleh hasil terbesar pada masa yang akan datang dari kekayaan atau aset yang ditanam. Menurut Jones (2002:3), investasi adalah penanaman modal dengan membeli satu atau lebih aset yang dimiliki selama beberapa waktu untuk mendapatkan keuntungan.

Pada umumnya investasi dibedakan menjadi dua, yaitu investasi pada aset kevangan dan investasi pada aset riil (Suryomurti, 2011:2). Aset kevangan adalah kegiatan penanaman modal pada lembaga keuangan (misalnya: perbankan dan pasar modal), contohnya seperti deposito, saham dan sukuk. Aset riil adalah bentuk kegiatan penanaman modal berupa aset fisik yang dapat dilihat, dirasakan, dan jelas bentuknya seperti investasi dalam properti, tanah dan logam mulia. Kedua jenis investasi tersebut mengacu pada tingkat perhitungan dalam pengembalian (return) dan kondisi tidak pasti yang berarti risiko di masa depan.

\section{Tujuan Investasi}

Pada dasarnya tujuan dalam berinvestasi adalah untuk memperoleh keuntungan di masa yang akan datang. Namun, pernyataan ini terlalu sederhana. Investor memiliki tujuan investasi yang mungkin berbeda satu dengan yang lainnya. Berbagai alasan investor dalam melakukan kegiatan investasi dapat dilihat dari beberapa tujuan yang ingin dicapai, seperti yang telah dikemukakan oleh Fahmi dan Hadi (2009:6), yaitu:

a. Terciptanya keberlanjutan (continuity) dalam investasi tersebut.

b. Terciptanya profit yang maksimum atau keuntungan yang diharapkan (profit actual).

c. Terciptanya kemakmuran bagi para pemegang saham.

d. Turut memberikan andil bagi pembangunan bangsa.

\section{Investasi dalam Perspektif Islam}

Investasi yang dilakukan oleh seorang muslim seharusnya dalam usaha mendekatkan diri kepada Allah SWT. Menurut pandangan Islam, investasi memiliki pengertian dan tujuan yang lebih luas karena mencakup aspek dunia (materi) dan akhirat (ukhrawi) seperti yang dijelaskan oleh Ryandono (2009:70):

Investasi syariah adalah pengorbanan sumber daya pada masa sekarang untuk mendapatkan hasil yang pasti, dengan harapan memperoleh hasil yang lebih besar di masa yang akan datang, baik langsung maupun tidak langsung seraya tetap berpijak pada prinsip-prinsip syariah secara menyeluruh (kaffah). Selain itu, semua bentuk investasi dilakukan dalam rangka ibadah kepada Allah untuk mencapai kebahagiaan lahir batin di dunia dan akhirat baik bagi generasi sekarang maupun generasi yang akan datang. 


\begin{abstract}
Dari pengertian dan tujuan investasi yang dikemukakan oleh Ryandono dapat terlihat jelas adanya perbedaan antara investasi syariah dengan investasi kapitalis, yaitu investasi syariah selalu mengacu pada prinsipprinsip syariah karena tujuannya tidak hanya untuk meraih keuntungan duniawi (materi) namun juga untuk meraih kemenangan di akhirat.
\end{abstract}

\section{Pasar Modal}

UU No. 8 tahun 1995 tentang Pasar Modal (UUPM) memberikan pengertian pasar modal yang lebih spesifik, yaitu kegiatan yang bersangkutan dengan penawaran umum dan perdagangan efek, perusahaan publik yang berkaitan dengan efek yang diterbitkannya, serta lembaga dan profesi yang berkaitan dengan efek. Karena pasar modal adalah tempat memperdagangkan efek, maka pasar modal disebut juga dengan bursa efek (Qamariyanti, 2009:2).

Pengertian pasar modal yang disebutkan dalam UU No. 8 tahun 1995, pasar modal syariah dapat diartikan sebagai kegiatan dalam pasar modal yang telah diatur dalam UUPM dan tidak bertentangan dengan prinsip syariah. Suryomurti (2011:118) juga mengartikan pasar modal syariah sebagai pasar modal yang menerapkan prinsip-prinsip syariah dalam kegiatan transaksi ekonomi dan terbebas dari hal-hal yang dilarang oleh ajaran islam, seperti riba, perjudian, spekulasi dan lain-lain, sehinggga sistem dalam pasar modal syariah tidak terpisah dari sistem pasar modal secara keseluruhan.

\section{Perbedaan Pasar Modal}

\section{Konvensional dan Pasar Modal Syariah}

Tabel 2.1 merupakan ringkasan perbedaan antara pasar modal konvensional dengan pasar modal syariah yang telah diungkapkan oleh beberapa pendapat para ahli, yaitu yang telah dijelaskan oleh Sholihin (2010:166), perbedaan mendasar antara pasar modal konvensional dengan pasar modal syariah dapat dilihat pada instrumen dan mekanisme transaksinya, sedangkan perbedaan nilai indeks saham syariah dengan nilai indeks saham konvensional terletak pada kriteria saham emiten yang harus memenuhi prinsip-prinsip dasar syariah.

Sama halnya yang dijelaskan oleh Suryomurti (2011:118) mengenai kegiatan yang dilakukan pasar modal konvensional juga ada hal-hal yang bertentangan dengan syariah, baik dari sisi akad, operasi, investasi, transaksi dan pembagian keuntungan. Sehingga, tidak ada batasan dan kriteria tertentu mengenai perusahaan penerbit saham.

Huda dan Nasution

(2007:57) menyebutkan bahwa sejumlah instrumen di pasar modal syariah sudah diperkenalkan kepada masyarakat seperti saham syariah, obligasi syariah dan reksadana syariah. Berbeda dengan instrumen yang ada di pasar modal konvensional, meliputi saham, obligasi, reksadana, opsi, waran dan right. Terdapat perbedaan antara pasar modal 
konvensional dengan pasar modal syariah. Perbedaan tersebut ditunjukkan pada tabel 2.1 sebagai berikut:

Tabel 1.

Perbedaan Pasar Modal Konvensional dengan Pasar Modal Syariah

\begin{tabular}{|c|c|c|c|}
\hline NO & INDIKATOR & $\begin{array}{l}\text { Pasar Modal } \\
\text { Syariah }\end{array}$ & $\begin{array}{l}\text { Pasar Modal } \\
\text { Konvensional }\end{array}$ \\
\hline 1. & Emiten & $\begin{array}{l}\text { Dari } \\
\text { perusahaan } \\
\text { yang } \\
\text { operasionalny } \\
\text { a tidak } \\
\text { melanggar } \\
\text { prinsip-prinsip } \\
\text { Islam. }\end{array}$ & $\begin{array}{l}\text { Tidak ada } \\
\text { batasan dan } \\
\text { kriteria tertentu } \\
\text { mengenai } \\
\text { perusahaan } \\
\text { penerbit } \\
\text { saham }\end{array}$ \\
\hline 2. & $\begin{array}{l}\text { Instrumen } \\
\text { yang } \\
\text { Diperdaga } \\
\text { ngkan }\end{array}$ & $\begin{array}{l}\text { Saham Syariah, } \\
\text { Obligasi } \\
\text { Syariah, } \\
\text { Reksadana } \\
\text { Syariah. } \\
\end{array}$ & $\begin{array}{l}\text { Saham, } \\
\text { obligasi, } \\
\text { reksadana, } \\
\text { opsi, waran, } \\
\text { right. }\end{array}$ \\
\hline 3. & $\begin{array}{l}\text { Jenis } \\
\text { Indeks }\end{array}$ & $\begin{array}{l}\text { a. Jika indeks } \\
\text { dikeluarkan } \\
\text { oleh emiten } \\
\text { konvensiona } \\
\text { l, maka } \\
\text { perhitungan } \\
\text { indeks } \\
\text { saham } \\
\text { digolongkan } \\
\text { memenuhi } \\
\text { kriteria- } \\
\text { kriteria } \\
\text { syariah. } \\
\text { b. Jika indeks } \\
\text { dikeluarkan } \\
\text { oleh emiten } \\
\text { syariah, } \\
\text { maka indeks } \\
\text { didasarkan } \\
\text { pada } \\
\text { seluruh } \\
\text { saham yang } \\
\text { terdaftar di } \\
\text { perusahaan } \\
\text { syariah. } \\
\end{array}$ & $\begin{array}{l}\text { Tidak ada } \\
\text { pemisahan } \\
\text { antara emiten } \\
\text { halal dan } \\
\text { haram. }\end{array}$ \\
\hline
\end{tabular}

Sumber: a. Solihin, Ahmad Ifham. 2010. Buku Pintar Ekonomi Syariah. Hal. 166. Jakarta: Gramedia Pustaka Utama.

b. Suryomurti, Wiku. 2011. Super Cerdas Investasi Syariah. Hal. 118. Jakarta: Qultum Media.

C. Huda, Nurul dan Mustafa Edwin Nasution. 2008. Investasi pada Pasar Modal Syariah. Edisi Revisi. Hal. 57. Jakarta: Kencana.

(Data diolah)

\section{Saham}

Pertiwi (2011:14) menyebutkan definisi saham yang disampaikan oleh BEI adalah surat berharga sebagai bukti penyertaan atau pemilikan individu maupun instituisi dalam suatu perusahaan. Dari pengertian yang lain diungkapkan oleh Huda dan Nasution (2007:60) bahwa saham merupakan surat bukti kepemilikan atas sebuah perusahaan yang melakukan penawaran umum (go public) dalam nominal ataupun persentase tertentu.

Kedua definisi di atas menunjukkan bahwa memiliki saham berarti memiliki perusahaan. Sesuai dengan pendapat yang disampaikan Hartono (2013:141), suatu perusahaan dapat menjual hak kepemilikannya dalam bentuk saham (stock). Pada dasarnya investor yang membeli saham karena melihat dari prospek perusahaan, apabila prospek perusahaan membaik maka harga saham juga akan meningkat.

\section{Saham Syariah}

Dewi (2010:14) mendefinisikan saham syariah merupakan saham yang memenuhi kriteria pemilihan saham syariah berdasarkan Peraturan Bapepam \& LK No.II.K.I tentang Kriteria dan Penerbitan Daftar Efek syariah, pasal 1.b.7. Kriteria tersebut telah diatur dalam Fatwa DSN No: 40/DSN-MUI/X/2003 Pasal 3 tentang Kriteria Emiten atau Perusahaan Publik, antara lain:

1. Jenis usaha, produk, jasa yang diberikan dan akad, serta cara pengelolaan perusahaan emiten atau perusahaan publik yang menerbitkan Efek Syariah tidak boleh bertentangan dengan prinsip-prinsip syariah, 
2. Jenis kegiatan usaha yang bertentangan dengan prinsip-prinsip syariah sebagaimana dimaksud dalam pasal 3 angka 1 di atas, antara lain:

a. Perjudian dan permainan yang tergolong judi atau perdagangan yang dilarang.

b. Lembaga keuangan konvensional (ribawi), termasuk perbankan dan asuransi konvensional.

c. Produsen, distributor, serta pedagang makanan dan minuman yang haram;

d. Produsen, distributor, dan/atau penyedia barang-barang atau jasa yang merusak moral dan bersifat mudarat.

e. Melakukan investasi pada emiten (perusahaan) yang pada saat transaksi tingkat (nisbah) hutang perusahaan kepada lembaga kevangan ribawi lebih dominan dari modalnya.

Selain itu, BEl melakukan tahaptahap pemilihan yang juga mempertimbangkan aspek likuiditas dan kondisi keuangan emiten (www.idx.co.id, 2010) yang mengacu pada Fatwa DSN No: 20/DSN-MUI/IX/2000 Pasal 10 tentang Kondisi Emiten yang Tidak Layak, yaitu:

a. Apabila struktur hutang terhadap modal sangat bergantung pada pembiayaan dari hutang yang pada intinya merupakan pembiayaan yang mengandung unsur riba;

b. Apabila suatu emiten memiliki nisbah hutang terhadap modal lebih dari $82 \%$ (hutang 45\%, modal 55\%). c. Apabila manajemen suatu emiten diketahui telah bertindak melanggar prinsip usaha yang islami.

Setelah tahap pemilihan di atas dilakukan, setiap tahunnya BEl akan melakukan pengkajian ulang setiap enam bulan sekali. Sesuai yang dikatakan Suryomurti (2011:139) bahwa komponen perhitungannya adalah semua saham yang masuk dalam Daftar Efek Syariah (DES) yang dikeluarkan oleh Bapepam-LK setiap enam bulan sekali. Perubahan ini akan terus di monitoring oleh BEl secara terus-menerus berdasarkan data-data publik yang tersedia.

\section{Tingkat Pengembalian (Return)}

Dalam melakukan kegiatan investasi pada saham, para investor perlu melihat apakah saham tersebut memberikan tingkat pengembalian (return) yang sesuai dengan harapan atau tidak. Menurut Jones (2002:130), return yang diperoleh pada saham terdiri dari dua komponen, yaitu Capital gain (loss) dan Yield. Capital gain (loss) merupakan selisih harga sekarang relatif terhadap harga periode sebelumnya. Yield merupakan komponen return aliran kas atau pendapatan yang diperoleh secara periodik dari suatu investasi. Dalam hal saham, yield diperlihatkan dari besarnya dividen yang diperoleh. Hartono (2013:235) juga membedakan return menjadi dua bagian, yaitu return realisasian (realized return) dan return ekspektasian (expected return).

Pengukuran return realisasi saham dapat dilakukan dengan cara 
menghitung selisih harga saham periode berjalan dengan harga saham periode sebelumnya. Sesuai dengan pengertian ini, maka perhitungan Realized Return saham ditunjukkan oleh Hartono (2013:236) pada persamaan 2.1 yang digunakan dalam sebuah penelitian berupa return bulanan.

$$
\mathrm{R}_{\mathrm{it}}=\frac{\mathrm{P}_{\mathrm{it}}-\mathrm{P}_{\mathrm{it}}-1}{\mathrm{P}_{\mathrm{it}}-1}
$$

Keterangan:

$\mathrm{R}_{\text {it }} \quad=$ return saham I pada bulan ke-

$\mathrm{P}_{\text {it }} \quad=$ harga saham I pada bulan ke-t

$\mathrm{P}_{\text {it }}-1$ = harga saham I 1 bulan sebelum bulan ke-

Sedangkan, return ekspektasian merupakan tingkat pengembalian yang diharapkan yang akan diperoleh investor di masa yang akan datang. Perhitungan expected return yang dikemukakan oleh Hartono (2013:253) dapat ditunjukkan pada persamaan 2.2 berikut ini.

$$
E(R i)=\sum_{1}^{n} \frac{R_{i t}}{n}
$$

Keterangan:

$$
\begin{aligned}
& E\left(R_{i}\right)=\text { return ekspektasian (expected } \\
& \text { return) saham I } \\
& \mathrm{R}_{\mathrm{it}}=\text { return saham I } \\
& \mathrm{N}=\text { jumlah dari hasil masa depan }
\end{aligned}
$$

\section{Risiko}

Tidaklah cukup jika dalam menilai kinerja saham hanya menghitung return saja, sehingga risiko juga perlu diperhitungkan. Karena return dan risiko merupakan dua hal yang tidak dapat dipisahkan. Suatu investasi yang memiliki risiko berarti investasi tersebut tidak akan memberikan keuntungan yang pasti. Keown (1999:199), medefinisikan risiko sebagai penyimpangan arus kas yang mungkin terjadi di masa yang akan datang.

Risiko pada dasarnya mencerminkan simpangan, maka metode pengukuran yang sering digunakan adalah deviasi standar seperti pada persamaan 2.3. Menurut Keown (1999:201), deviasi standar adalah akar dari rata-rata penyimpangan pangkat dua dari setiap kemungkinan pengembalian terhadap pengembalian yang diharapkan.

$$
\sigma_{i}=\sqrt{\sum_{i=1}^{n} \frac{\left[\left(R_{i t}-\bar{R}_{i t}\right)\right]^{2}}{n-1}}
$$

Keterangan:

$\sigma_{i} \quad=$ deviasi standar return saham $\mathrm{i}$

$\begin{array}{ll}\frac{\mathrm{n}}{\mathrm{R}_{\mathrm{it}}} & =\text { periode saham } \\ & =\text { rata-rata return saham } \mathrm{i}\end{array}$

Dalam pengukuran deviasi standar dapat menunjukkan seberapa besar penyebaran nilai tingkat pengembalian pada suatu nilai yang diharapkan. Dengan kata lain, semakin besar deviasi standar pengembalian, semakin besar penyimpangan hasil pengembalian, semakin besar risiko investasi (Horne dan Wachowicz, 1997:96). Return dan risiko merupakan dua hal berpasangan yang selalu menjadi perhatian dalam menilai kinerja saham. Secara umum, suatu investasi yang memiliki risiko tinggi berpotensi memberikan return yang tinggi pula, dan demikian sebaliknya. Oleh karena itu, analisis return dan risiko sering dilakukan para pelaku pasar modal.

\section{Koefisien Variasi}


Dalam melakukan analisis investasi, terdapat dua faktor yang harus dipertimbangkan secara bersama-sama, yaitu return ekspektasian dan risiko. Menurut Brigham dan Houston (2001:186):

Jika sebuah pilihan harus diambil di antara dua investasi yang mempunyai pengembalian diharapkan yang sama tetapi mempunyai deviasi standar yang berbeda, maka hampir semua orang akan memilih salah satu yang memiliki deviasi standar terendah, dan oleh karena itu, risiko yang lebih rendah. Demikian juga, pilihan di antara dua investasi dengan risiko yang sama (deviasi standar) tetapi memiliki pengembalian yang diharapkan berbeda, maka investor akan lebih menyukai investasi dengan pengembalian yang diharapkan lebih tinggi.

Penjelasan yang dikemukakan oleh Brigham dan Houston menunjukkan bahwa hampir semua investor menginginkan pengembalian yang lebih besar dengan risiko yang rendah. Berdasarkan penjelasan di atas jika dalam memilih di antara dua investasi memiliki tingkat pengembalian (return) dan risiko yang sama, maka diperlukan perhitungan koefisien variasi. Pengukuran yang digunakan dalam menghitung koefisien variasi adalah deviasi standar dibagi dengan expected return, atau dapat dirumuskan oleh Horne dan Wachowicz (1997:98) dalam persamaan 2.4.

$$
C V=\frac{\sigma_{i}}{E\left(R_{i}\right)}
$$

Keterangan:

$\mathrm{CV}=$ koefisien Variasi

$\sigma_{i} \quad=$ deviasi standar saham $\mathrm{i}$

$E\left(R_{i}\right) \quad=$ expected return saham $i\left(\bar{R}_{i}\right)$
Rumus koefisien variasi yang ditunjukkan persamaan 2.4, Hartono (2013: 262) mengartikan bahwa semakin kecil nilai CV semakin baik aktiva tersebut. Semakin kecil CV menunjukkan semakin kecil risiko aktiva dan semakin besar return ekspektasiannya.

\section{Hipotesis}

1. Terdapat perbedaan yang signifikan antara tingkat pengembalian (return) pada saham syariah dan saham non syariah di Bursa Efek Indonesia (BEI) periode $2011-2013$.

2. Terdapat perbedaan yang signifikan antara risiko pada saham syariah dan saham non syariah di Bursa Efek Indonesia (BEI) periode 2011-2013.

3. Terdapat perbedaan yang signifikan antara koefisien variasi pada saham syariah dan saham non syariah di Bursa Efek Indonesia (BEI) periode 2011-2013.

\section{Model Analisis}

Dari hipotesis di atas, maka model analisis yang digunakan dalam penelitian ini adalah model analisis varabel penelitian dan analisis selisih dua rata-rata.

Untuk menentukan saham mana yang memiliki kinerja yang paling bagus, oleh karena itu perlu dilakukan perhitungan tingkat pengembalian (return), risiko dan koefisien variasi saham syariah dan saham non syariah. Setelah itu dari hasil perhitungan tersebut akan dilakukan analisis variabel penelitian dan selanjutnya akan dilakukan uji statistic, yaitu uji beda dengan menggunakan uji- $\dagger$ dua sampel independen (Independent- 
Samples + Test). Dari hasil uji-† tersebut, kemudian dibuat kesimpulan tentang signifikansi perbedaan tingkat pengembalian (return), risiko dan koefisien variasi pada saham syariah dan saham non syariah di Bursa Efek Indonesia (BEI) periode 2011-2013.

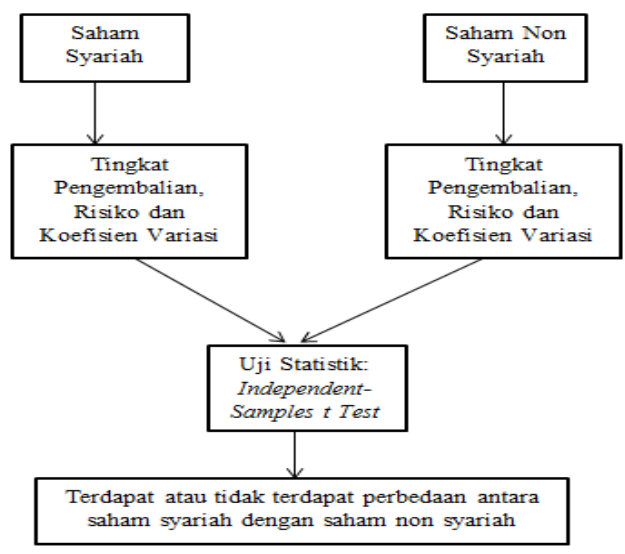

Gambar 1.

Model Analisis

\section{METODOLOGI PENELITIAN}

Penelitian ini dilakukan dengan menggunakan pendekatan kuantitatif, yaitu penelitian yang menitikberatkan pada pengujian hipotesis, mengukur variabel yang sedang diteliti dan akan menghasilkan kesimpulan yang dapat digeneralisasikan, serta menggunakan alat bantu statistik.

\section{Identifikasi Variabel}

Untuk menjawab rumusan masalah dan menguji hipotesis, maka variabel yang digunakan dalam penelitian ini adalah tingkat pengembalian (return), risiko dan koefisien variasi.

\section{Definisi Operasional Variabel}

Untuk memberikan gambaran yang jelas mengenai variabel yang digunakan dalam penelitian ini, maka variabel tersebut dapat didefinisikan sebagai berikut:

a. Tingkat Pengembalian (Return)

Return merupakan ukuran tingkat pengembalian yang didapatkan atas suatu investasi. Return dari berinvestasi saham didapatkan dari capital gain atau loss. Data return yang berasal dari harga saham bulanan tahun 2011 2013 ini merupakan data rasio dan bersifat cross section karena dia mbil dari rata-rata harga perusahaan dalam satu waktu (2011-2013). Return realisasi (realized return) yang digunakan dalam penelitian ini adalah return bulanan selama 3 tahun, yaitu mulai dari tahun 2011 hingga 2013 yang menghasilkan capital gain atau loss pada beberapa saham dan dihitung dalam bulanan sesuai dengan persamaan 2.1. Pada return ekspektasian (expected return) dapat dihitung dari hasil rata-rata return realisasi bulanan pada tahun 2011 hingga 2013 dengan menggunakan persamaan 2.2.

b. Risiko

Risiko merupakan penyimpangan yang terjadi dari masing-masing return saham yang dianalisis. Ukuran risiko yang digunakan dalam penelitian ini adalah deviasi standar. Data deviasi standar yang berasal dari return saham bulanan tahun 2011-2013 ini merupakan data rasio dan bersifat cross section yang dihitung melalui return ekspektasian (expected return). Perhitungan deviasi standar dihitung 
dengan menggunakan persamaan 2.3.

c. Koefisien Variasi

Koefisien variasi merupakan suatu pengukuran yang dilakukan untuk membandingkan kedua variabel secara bersama-sama, yaitu return ekspektasi dan deviasi standar. Data koefisien variasi yang berasal dari return ekspektasi dan deviasi standar pada saham bulanan tahun 2011-2013 ini merupakan data rasio dan bersifat cross section. Perhitungan koefisien variasi mengacu pada persamaan 2.4.

\section{Jenis dan Sumber Data}

Dalam penelitian ini, keseluruhan datanya adalah data sekunder yang dapat diperoleh melaui media internet khususnya data mengenai harga saham dalam bulanan yang diakses melalui www.yahoofinance.co.id, serta beberapa sumber literatur lain yang menunjang penelitian ini.

Data sekunder yang digunakan dalam penelitian ini berupa data harga saham bulanan yang tercatat di BEl pada tahun 2011-2013.

\section{Populasi dan Sampel}

Populasi dalam penelitian ini adalah saham syariah dan non syariah yang tercatat di Bursa Efek Indonesia (BEI) dalam kurun waktu penelitian (2011-2013).

Metode pemilihan sampel yang digunakan dalam penelitian ini adalah sampel acak (probability sampling). Pengambilan sampel acak tersebut dilakukan dengan cara mengundi. Selanjutnya akan dipilih sebanyak 10 saham syariah dan 10 saham non syariah. Nama-nama saham yang keluar tersebut akan dijadikan sampel.

\section{Teknik Analisis}

Dalam penelitian ini, teknik analisis yang digunakan ialah teknik analisis uji- $\dagger$ dua sampel independen (IndependentSamples $t$ Test). Berikut langkah-langkah yang diambil untuk melakukan analisis dalam penelitian ini, antara lain:

1. Menghitung rasio-rasio keuangan yang ditentukan dalam penelitian ini (return realisasi, expected return, risiko dan koefisien variasi).

2. Uji normalitas menggunakan OneSample Kolmogorov Smirnov Test dengan tingkat sig. 5\%. Pengujian normalitas ini untuk mengetahui apakah data berdistribusi dengan normal atau tidak dan untuk menentukan jenis alat analisis yang digunakan untuk melakukan uji beda (parametrik atau non parametrik).

3. Uji beda dengan menggunakan uji- $\dagger$ dua sampel berpasangan untuk data berdistribusi normal dan Uji MannWhitney untuk data yang tidak berdistribusi normal.

\section{HASIL DAN PEMBAHASAN}

Penelitian dilakukan dengan menggunakan sampel acak antara lain 10 saham syariah dan 10 saham non syariah yang dapat dilihat dalam tabel 1. dan tabel 2. 


\begin{tabular}{|c|c|l|}
\hline No. & Kode & \multicolumn{1}{|c|}{ Nama Saham } \\
\hline 1 & ARNA & PT Arwana Citramulia Tbk. \\
\hline 2 & CNKO & PT Exploitasi Energi Indonesia Tbk. \\
\hline 3 & CTRS & PT Ciputra Surya Tbk. \\
\hline 4 & DILD & PT Intiland Development Tbk. \\
\hline 5 & DVLA & PT Darya Varia Laboratoria Tbk. \\
\hline 6 & MKPI & PTMetropolitan Kentjana Tbk. \\
\hline 7 & PLIN & PT Plaza Indonesia Realty Tbk. \\
\hline 8 & PTBA & PT Tambang Batubara Bukit Asam (Persero) Tbk. \\
\hline 9 & SMCB & PT Holcim Indonesia Tbk. \\
\hline 10 & TCID & PTMandom Indonesia Tbk. \\
\hline
\end{tabular}

Tabel 3.

Saham Non Syariah

\begin{tabular}{|c|c|l|}
\hline No. & Kode & \multicolumn{1}{|c|}{ Nama Saham } \\
\hline 1 & AIRT & PT Sumber Alfaria Trijaya Tbk. \\
\hline 2 & APIC & PT Pacific Strategic Financial Tbk. \\
\hline 3 & CPRO & PT Central Proteinaprima Tbk. \\
\hline 4 & KONI & PT Perdana Bangun Pusaka Tbk. \\
\hline 5 & MIRX & PT Hanson International Tbk. \\
\hline 6 & POLY & PT Asia Pacific Fibers Tbk. \\
\hline 7 & RUTS & PT Radiant Utama Interinsco Tbk. \\
\hline 8 & SCPI & PTMerck Sharp Dohme Pharma Tbk. \\
\hline 9 & TMAS & PT Pelayaran Tempuran Emas Tbk. \\
\hline 10 & TRUS & PT Trust Finance Indonesia Tbk. \\
\hline
\end{tabular}

Berdasarkan data di atas selanjutnya dihitung realized return bulanan berdasarkan data historis closing price, kemudian dilakukan perhitungan expected return, risiko dan koefisien variasi pada saham syariah dan saham non syariah dalam bulanan dari tahun 20112013 (periode pengamatan). Perhitungan dalam penelitian ini diukur berdasarkan data bulanan dari tahun 2011 hingga 2013, sehingga terdapat 36 data (N) yang diperoleh dalam penelitian ini.

\section{Uji Normalitas}

Tabel 4.
Hasil Uji Normalitas One Sample Kolmogorov Smirnov Test

\begin{tabular}{|c|c|c|c|c|}
\hline & Saham & Sig. & Keterangan & Pengujian \\
\hline \multirow{2}{*}{$\begin{array}{l}\text { Tingkat } \\
\text { Pengembali } \\
\text { an (Return) }\end{array}$} & $\begin{array}{l}\text { Saham } \\
\text { Syariah }\end{array}$ & 0,200 & $\begin{array}{c}\text { Berdistribusi } \\
\text { Normal }\end{array}$ & $\begin{array}{l}\text { Independent } \\
\text { Samples t-Test }\end{array}$ \\
\hline & $\begin{array}{c}\text { Saham Non } \\
\text { Syariah }\end{array}$ & 0,001 & $\begin{array}{c}\text { Tidak } \\
\text { Berdistribusi } \\
\text { Normal }\end{array}$ & Mann-Whitney U \\
\hline \multirow[t]{2}{*}{ Risiko } & $\begin{array}{l}\text { Saham } \\
\text { Syariah }\end{array}$ & 0,000 & $\begin{array}{c}\text { Tidak } \\
\text { Berdistribusi } \\
\text { Normal }\end{array}$ & Mann-Whitney U \\
\hline & $\begin{array}{c}\text { Saham Non } \\
\text { Syariah }\end{array}$ & 0,004 & $\begin{array}{c}\text { Tidak } \\
\text { Berdistribusi } \\
\text { Normal }\end{array}$ & Mann-Whitney U \\
\hline \multirow[t]{2}{*}{$\begin{array}{l}\text { Koefisien } \\
\text { Variasi }\end{array}$} & $\begin{array}{l}\text { Saham } \\
\text { Syariah }\end{array}$ & 0,000 & $\begin{array}{c}\text { Tidak } \\
\text { Berdistribusi } \\
\text { Normal }\end{array}$ & Mann-Whitney U \\
\hline & $\begin{array}{c}\text { Saham Non } \\
\text { Syariah }\end{array}$ & 0,000 & $\begin{array}{c}\text { Tidak } \\
\text { Berdistribusi } \\
\text { Normal }\end{array}$ & Mann-Whitney U \\
\hline
\end{tabular}

Sumber: Data diolah

Berdasarkan tabel 4 dapat diketahui bahwa data tingkat pengembalian (return) dari saham syariah berdistribusi secara normal, sedangkan tingkat pengembalian (return) dari saham non syariah tidak berdistribusi secara normal. Selain itu juga diketahui data risiko dan koefisien variasi dari kedua grup saham tersebut tidak berdistribusi secara normal.

Dari hasil data pada tingkat pengembalian (return) dikarenakan terdapat data tidak berdistribusi secara normal, maka alat uji yang digunakan adalah Mann-Whitney U. Begitu juga dengan risiko dan koefisien variasi, alat uji yang akan digunakan untuk menguji hipotesis dalam penelitian ini ialah MannWhitney U.

\section{Uji Mann Whitney U}

Pengujian hipotesis yang dilakukan pada penelitian ini menggunakan MannWhitney $U$ ini digunakan tingkat signifikansi sebesar $5 \%(0,05)$.

$$
H_{0}: \eta_{1}=\eta_{2}
$$$$
H_{1}: \eta_{1} \neq \eta_{2}
$$

Apabila hasil dari Mann-Whitney $U$ menunjukkan bahwa nilai sig lebih besar 
dari tingkat signifikansi yaitu $5 \%(0,05)$, maka $\mathrm{H}_{0}$ diterima. Begitu pula sebaliknya apabila pada hasil Mann-Whitney $U$ menunjukkan bahwa nilai .sig lebih kecil dari tingkat signifikansi $5 \%(0,05)$, maka hal ini berarti $\mathrm{H}_{0}$ ditolak dan $\mathrm{H}_{1}$ diterima. Berikut ialah hasil dari uji hipotesis menggunakan Mann-Whitney $U$.

Tabel 5.

Hasil Uji Mann Whitney U

\begin{tabular}{|l|c|c|c|c|c|}
\hline & Nilai $\mathbf{l}$ & Sig. & A & $\begin{array}{c}\text { Keputusan } \\
\text { HO }\end{array}$ & Kesimpulan \\
\hline $\begin{array}{l}\text { Tingkat } \\
\text { Pengembalian }\end{array}$ & $-0,670$ & 0,503 & 0,05 & Ho Diterima & $\begin{array}{l}\text { TidakTerdapat } \\
\text { perbedaan } \\
\text { yang signifkan }\end{array}$ \\
\hline Risiko & $-0,113$ & 0,910 & 0,05 & Ho Diterima & $\begin{array}{l}\text { Tidak terdapat } \\
\text { perbedaan } \\
\text { yang signifikan }\end{array}$ \\
\hline $\begin{array}{l}\text { Koefisien } \\
\text { Variasi }\end{array}$ & $-0,997$ & 0,319 & 0,05 & Ho Diterima & $\begin{array}{l}\text { Tidak terdapat } \\
\text { perbedaan } \\
\text { yang signifikan }\end{array}$ \\
\hline
\end{tabular}

Sumber: Data diolah

\section{Perbandingan Tingkat Pengembalian}

(Return) pada Saham Syariah dan Saham Non Syariah di Bursa Efek Indonesia (BEI) Periode 2011-2013

Berdasarkan tabel 4. dapat diketahui nilai P-value (.sig) dari variabel tingkat pengembalian (return) ialah 0,503. Nilai Pvalue (.sig) tersebut lebih besar dari nilai a $(0,05)$, ini berarti hipotesis awal $\left(\mathrm{H}_{0}\right)$ diterima dan $\mathrm{H}_{1}$ ditolak. Sehingga dengan kata lain dapat disimpulkan bahwa tingkat pengembalian (return) pada saham syariah dan saham non syariah tidak terdapat perbedaan yang signifikan.

Perbandingan Risiko pada Saham Syariah dan Saham Non Syariah di Bursa Efek Indonesia (BEI) Periode 2011-2013
Berdasarkan tabel 4.4, dapat diketahui nilai P-value (.sig) dari variabel risiko ini ialah 0,910. Nilai P-value (.sig) tersebut lebih besar dari nilai a $(0,05)$, ini berarti hipotesis awal $\left(\mathrm{H}_{0}\right)$ tidak dapat ditolak. Sehingga dengan kata lain dapat disimpulkan bahwa risiko pada saham syariah dan saham non syariah tidak terdapat perbedaan yang signifikan.

Perbandingan Koefisien Variasi pada Saham Syariah dan Saham Non Syariah di Bursa Efek Indonesia (BEI) Periode 20112013

Berdasarkan tabel 4.4, dapat diketahui nilai P-value (.sig) dari variabel koefisien variasi ini ialah 0,319. Nilai P-value (.sig) tersebut lebih besar dari nilai a $(0,05)$, ini berarti hipotesis awal $\left(\mathrm{H}_{0}\right)$ tidak dapat ditolak. Sehingga dengan kata lain dapat disimpulkan bahwa koefisien variasi pada saham syariah dan saham non syariah tidak terdapat perbedaan yang signifikan.

\section{Pembahasan}

a. Tingkat Pengembalian (Return)

Menurut kesimpulan hasil uji hipotesis dari tingkat pengembalian (return) ialah $\mathrm{H}_{0}$ diterima (tabel 4.4), yang artinya tidak terdapat perbedaan yang signifikan antara tingkat pengembalian (return) pada saham syariah dan saham non syariah. Tidak adanya perbedaan yang signifikan ini disebabkan karena kedua jenis saham tersebut memiliki karakteristik yang hampir sama. Kondisi seperti ini dikarenakan kinerja yang telah dilakukan kurang memuaskan. Dalam hal ini Keown (2010:55) menjelaskan bahwa Perkiraan keuntungan tidak selalu tercapai, dan 
tergantung pada perusahaan untuk mengatur usahanya agar bisa mencapai nilai setinggi mungkin dari investasi tersebut.

Penelitan Kurniadi dkk (2013:65) menjelaskan bahwa dalam penentuan return saham selain dipengaruhi oleh kinerja perusahaan juga dipengaruhi faktor eksternal. Adanya faktor makroekonomi, dapat mengakibatkan return pasar memiliki hubungan searah dengan return saham syariah dan saham non syariah.

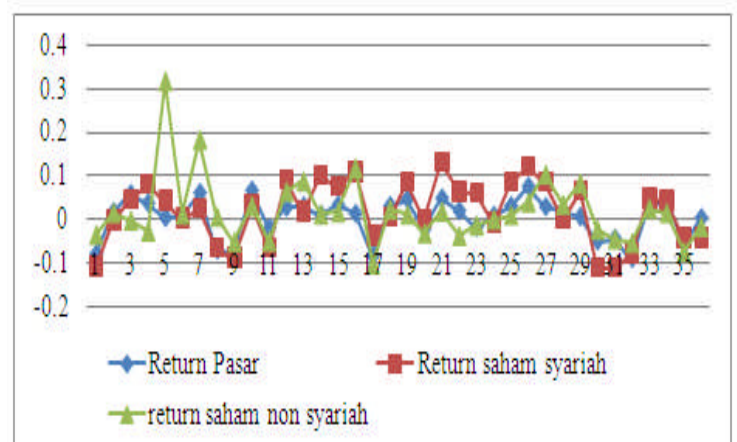

Sumber: Data diolah

Gambar 2.

Pergerakan Tingkat Pengembalian (Return) Pasar, Saham Syariah dan Saham Non Syariah di Bursa Efek Indonesia (BEI) Periode tahun 2011-2013

Hasil penelitian yang menunjukkan tidak ada perbedaan antara tingkat pengembalian (return) pada saham syariah dan saham non syariah ini konsisten dengan hasil penelitian sebelumnya. Pada penelitian Wijiyantoro (2013) menunjukkan tidak terdapat perbedaan yang signifikan return saham Jakarta Islamic Index dan LQ45. Dengan kata lain, $\mathrm{H}_{\circ}$ diterima dan $\mathrm{H}_{1}$ ditolak.

Hasil uji statistik dengan menggunakan uji beda juga dilakukan oleh Fahmi (2011) bahwa tidak ada perbedaan yang signifikan terhadap return saham Jll dan LQ45. Begitu pula pada hasil penelitian Hanafi dan Hanafi (2013) yang diukur dengan rasio sharpe, rasio treynor dan rasio Jensen dan diketahui hasil nilai probabilitas di atas nilai sig. (5\%), maka disimpulkan tidak ada perbedaan yang signifikan antara JII dan LQ45.

Berdasarkan pembahasan di atas dapat menggambarkan bahwa minat investor dalam berinvestasi pada saham tidak hanya melihat dari sisi syariahnya saja, tetapi juga melihat dari kondisi perusahaan, yaitu baik dari sisi laporan keuangannya, maupun melihat dari citra perusahaan, dan lain sebagainya yang dapat mempengaruhi kondisi perusahaan tersebut.

b. Risiko

Menurut hasil uji hipotesis, kesimpulan dari risiko ini ialah $\mathrm{H}_{0}$ diterima (tabel 4.4), yang artinya tidak terdapat perbedaan yang signifikan antara risiko pada saham syariah dan saham non syariah di Bursa Efek Indonesia (BEI). Tidak adanya perbedaan yang signifikan antara risiko pada saham syariah dan saham non syariah bisa jadi dipengaruhi oleh kinerja perusahaan. Misalnya, jika dilihat melalui laporan kevangannya mengenai Earning Per Share (EPS) yang mana pada saat EPS pada perusahaan itu naik sekian persen, berarti terdapat peningkatan pada volume pendapatan, sehingga kondisi perusahaan tersebut dapat dikatakan baik. Pada gambar 4.2, simpangan yang terjadi pada tingkat pengembalian 
saham syariah dan saham non syariah berbeda-beda pada tiap periodenya.

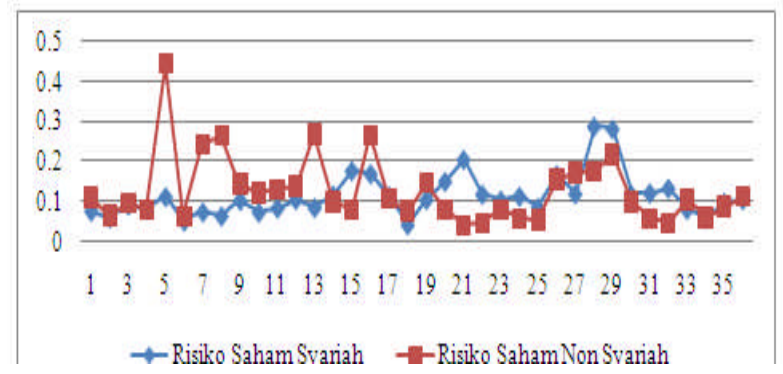

Sumber: Data diolah

Gambar 2.

Pergerakan Risiko pada Saham Syariah dan Saham Non Syariah di Bursa Efek Indonesia (BEI) Periode tahun 201 1-2013

Pergerakan risiko di atas menunjukkan hasil penelitian ini tidak terdapat perbedaan antara saham syariah dengan saham non syariah, sehingga kesimpulan dalam penelitian ini konsisten dengan hasil penelitian sebelumnya. Hasil perhitungan statistik pada penelitian Wijiyantoro (2013) menunjukkan tidak terdapat perbedaan yang signifikan risiko saham Jakarta Islamic Index dan LQ45.

Pada hasil uji statistik dengan menggunakan uji beda yang dikenal dengan uji $†$ juga telah dilakukan oleh Fahmi (2011) menunjukkan hasil nilainya di atas nilai sig. $(0,05)$, sehingga dapat disimpulkan bahwa tidak ada perbedaan yang signifikan terhadap risiko saham JII dan LQ45, dengan kata lain $\mathrm{H}_{\circ}$ diterima dan $\mathrm{H}_{1}$ ditolak. Begitu pula pada hasil penelitian Hanafi dan Hanafi (2013) yang diukur dengan rasio sharpe, rasio treynor dan rasio Jensen. Pengujian dilakukan dengan menggunakan t-test (sig. 5\%) untuk melihat ada tidaknya perbedaan yang signifikan antara JII dan LQ45. Kesimpulan dari hasil penelitiannya adalah tidak ada perbedaan yang signifikan antara JII dan LQ45.

Beberapa hasil penelitian terdahulu yang disimpulkan oleh Hanafi dan Hanafi (2013) mengatakan bahwa mekanisme screening tidak mempengaruhi kinerja perusahaan yang tergabung dalam saham syariah, sehingga wajar jika tidak ada perbedaan risiko antara saham syariah dan saham non syariah.

Berdasarkan pembahasan di atas, prinsip syariah pada saham tersebut belum menjadi faktor utama bagi investor dalam memilih saham yang akan dibelinya. Hal inilah yang menyebabkan tidak ada perbedaan pada risiko, sehingga perusahaan yang sahamnya tergolong saham syariah perlu melihat kembali apa yang telah dilakukan selama ini sudah maksimal atau belum.

c. Koefisien Variasi

Menurut hasil uji hipotesis (tabel 4.4), kesimpulan dari koefisien variasi pada penelitian ini ialah $\mathrm{H}_{0}$ diterima, yang artinya tidak terdapat perbedaan yang signifikan antara koefisien variasi pada saham syariah dan saham non syariah di Bursa Efek Indonesia (BEI).

Tidak adanya perbedaan yang signifikan antara koefisien variasi pada saham syariah dan saham non syariah ini dikarenakan hasil uji hipotesis dari variabel risiko pada penelitian ini juga disimpulkan tidak berbeda secara signifikan sehingga berdampak pada hasil uji hipotesis pada variabel koefisien variasi ini. Penjelasan yang dikemukakan Rahman (2005:187) menyatakan bahwa pengukuran koefisien 
variasi dipakai oleh analisis keuangan untuk membandingkan beberapa jenis investasi dengan tingkat keuntungan ekspektasi dan standar deviasi yang berbeda-beda.

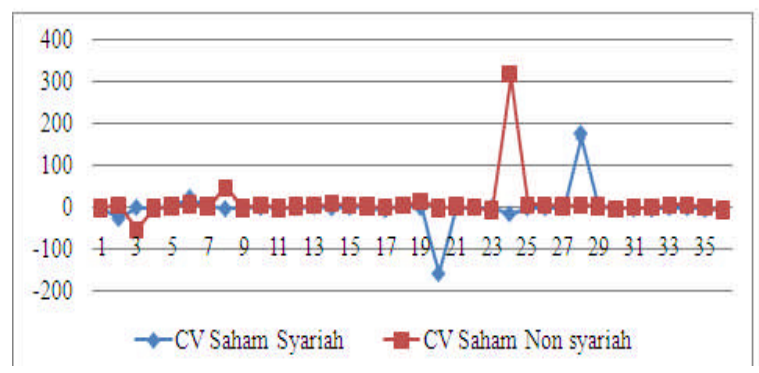

Sumber: Data diolah

Gambar 3.

Pergerakan Koefisien Variasi pada Saham Syariah dan Saham Non Syariah di Bursa

Efek Indonesia (BEI) Periode 2011-2013

Perhitungan koefisien variasi dapat digunakan untuk melihat seberapa besar risiko per unit pengembalian yang dimiliki suatu investasi pada saham. Pada dasarnya risiko mencerminkan simpangan, maka besarnya simpangan yang terjadi pada tingkat pengembalian kedua jenis saham tersebut menandakan bahwa semakin tinggi simpangan menandakan risiko yang semakin besar. Namun, dikarenakan bentuk pengukuran dalam penelitian ini adalah portofolio saham, maka Hartono (2013:308) menjelaskan terdapat dua risiko, yaitu risiko sistematis (systematic risk) dan risiko tidak sistematis (unsystematic risk).

Systematic risk merupakan risiko yang terjadi karena kejadian-kejadian di luar kegiatan perusahaan, seperti inflasi, resesi dan lain sebagainya. Sedangkan, unsystematic risk merupakan risiko yang dapat dihilangkan dengan melakukan diversifikasi, karena risiko ini hanya ada di suatu perusahaan tertentu, seperti, pemogokan buruh, tuntutan oleh pihak lain, penelitian yang tidak berhasil dan lain sebagainya.
Sesuai dengan penjelasan di atas menandakan bahwa setiap perusahaan saham pasti dipengaruhi dengan adanya risiko sistematis (systematic risk) dan risiko tidak sistematis (unsystematic risk), sehingga wajar jika risiko per unit pengembalian yang dimiliki oleh saham syariah dan saham non syariah bisa tidak berbeda secara signifikan.

Hasil penelitian seperti ini konsisten dengan penelitian sebelumnya. Sesuai dengan Hanafi dan Hanafi (2013) diketahui hasil penelitiannya memiliki nilai di atas tingkat sig. 0,05 dan kesimpulannya adalah tidak ada perbedaan kinerja yang signifikan antara JII dan LQ45. Dengan kata lain, semua $\mathrm{H}_{\circ}$ diterima dan $\mathrm{H}_{1}$ ditolak. Hal ini menunjukkan bahwa meskipun saham tersebut sudah sesuai dengan syariah, namun bukan berarti saham tersebut tidak memiliki risiko.

\section{SIMPULAN}

1. Tidak terdapat perbedaan signifikan antara tingkat pengembalian (return) dari saham syariah dan saham non syariah di Bursa Efek Indonesia (BEI) dengan tingkat signifikansi sebesar $5 \%$ $(a=0,05)$.

2. Tidak terdapat perbedaan yang signifikan antara risiko dari saham syariah dan saham non syariah di Bursa Efek Indonesia (BEI) dengan tingkat signifikansi sebesar $5 \%(a=0,05)$.

3. Tidak terdapat perbedaan yang signifikan antara koefisien variasi (risiko per unit pengembalian) dari saham syariah dan saham non syariah di 
Bursa Efek Indonesia (BEI) dengan tingkat signifikansi sebesar $5 \%(a=0,05)$. Hasil penelitian ini konsisten pada penelitian sebelumnya. Mekanisme screening tidak mempengaruhi kinerja perusahaan yang tergabung dalam saham syariah, sehingga wajar jika tidak ada perbedaan antara return, risiko dan koefisien variasi saham syariah dan saham non syariah.

\section{DAFTAR PUSTAKA}

Astuti, Dwi dan Toto Sugiharto. 2005. Analisis Pembentukan Portofolio Optimal pada Perusahaan Industri Plastic dan Packaging yang Terdaftar di Bursa Efek Jakarta Studi Kasus (19992003). Proceding, Seminar Nasional PESAT, Auditorium Universitas Gunadarma, Jakarta.

Brigham, Eugene F. and Joel F. Houston (2001). Manajemen Keuangan, terjemahan Dodo Suharto dan Herman Wibowo. Edisi kedelapan. Jakarta: Erlangga.

Dewan Syariah Nasional. 2000. Fatwa DSNMUI No: 20/DSN-MUI/IX/2000 tentang Kondisi Emiten yang Tidak Layak. (online) www.bapepam.com diakses pada tanggal 15 September 2014.

Fatwa DSN No: 40/DSNMUI/X/2003 tentang Kriteria Emiten atau Perusahaan Publik. (online) www.bapepam.com diakses pada tanggal 15 September 2014.

Fatwa No. 80/DSNMUI/III/2011 tentang Penerapan Prinsip Syariah dalam Mekanisme Perdagangan Efek Bersifat Ekuitas di
Pasar Regular Bursa Efek. (online) www.bapepam.com diakses pada tanggal 28 Oktober 2014.

Dewi, Friderica Widyasari. 2010. Kinerja Pasar Modal Syariah di Indonesia. Makalah disajikan dalam Seminar 'Pasar Modal Syariah'. Jakarta.

Djazuli, A. 2011. Kaidah-Kaidah Fikih: Kaidah-Kaidah Hukum Islam dalam Menyelesaikan Masalah yang Praktis. Jakarta: Kencana.

Fahmi, Irham dan Yovi Lavianti Hadi. 2009. Teori Portofolio dan Analisis Investasi, Teori dan Soal Jawab. Bandung: Alfabeta.

Fahmi, Johan Tri Marhadi. 2011. Analisis Perbandingan Risk and Return Saham Syariah dengan Saham Konvensional (Studi pada Saham LQ45 dan JII di Bursa Efek Indonesia Periode 20052008). Tesis tidak diterbitkan. Malang: Universitas Brawijaya.

Hartono, Jogiyanto. 2009. Teori Portofolio dan Analisis Investasi. Edisi Keenam. Yogyakarta: BPFE.

Horne, James C. Van dan Jhon M. Wachowicz. Prinsip-Prinsip Manajemen Keuangan. Edisi Kesembilan. Terjemahan oleh Heru Sutojo. 1997. Jakarta: Salemba Empat.

Huda, Nurul dan Mustafa Edwin Nasution. 2008. Investasi pada Pasar Modal Syariah. Edisi Revisi. Jakarta: Kencana. Jones, Charles P. 2002. Investment Analysis and Management. Edisi Kedelapan. New York: John Wiley \& Sons, Inc.

Keown, Arthur J. Dasar-dasar Manajemen Keuangan. Edisi ketujuh. Terjemahan 
oleh Chaerul D. Djakman. 1999. Jakarta: Salemba Empat.

Kurniadi, Arif, dkk. 2013. Kinerja Keuangan Berbasis Penciptaan Nilai, Faktor Makroekonomi dan Pengaruhnya Terhadap Return Saham Sektor Pertanian. Jurnal Akuntansi dan Keuangan, XV (2): 63-74.

Pertiwi, Nia Wirawati. 2011. Pengaruh Kinerja Kevangan terhadap Pendapatan Saham Sebelum dan Sesudah Saham Terdaftar di Jakarta Islamic Index (JII). Skripsi tidak diterbitkan. Surabaya: Universitas Airlangga Surabaya.

Qamariyanti, Tavinayati Yulia. 2009. Hukum Pasar Modal di Indonesia. Jakarta: Sinar Grafika.

Rahman, Abdulah. 2005. Analisis Portofolio Optimal pada Saham LQ45 dengan Pemrograman Non Linier. Jurnal Ekonomi Perusahaan, XII (2): 183-195.

Riyandono, Muhamad Nafik H. 2009. Bursa Efek dan Investasi Syariah. Jakarta: Serambi.

Solihin, Ahmad Ifham. 2010. Buku Pintar Ekonomi Syariah. Jakarta: Gramedia Pustaka Utama.

Suryomurti, Wiku. 2011. Super Cerdas Investasi Syariah. Jakarta: Qultum Media.

www.bapepam.go.id, diakses pada tanggal 12 September 2014.

www.idx.co.id, diakses pada tanggal 15 Oktober 2014 www.yahoofinance.co.id, diakses pada tanggal 26 September 2014 